\title{
INNOVATIONS IN MARKETING STRATEGIES OF NEWS PAPER INDUSTRY IN INDIA - A CASE STUDY OF TIMES OF INDIA GROUP
}

Dr M. K. Sridhar $\dagger$

A. R. Sainath $\dagger$

\begin{abstract}
Newspapers have become products like any other consumer, industrial or service products. They have unique features which other products do not have. The newspaper industry in India is witnessing intense competition from within and from outside like electronic and internet media. This has tremendous bearing on circulation and advertisement revenues.
\end{abstract}

The industry has responded proactively to these challenges. There is more and more focus on marketing and innovations in marketing strategies. Reviews of some of these strategies are focused in the paper.

The authors have presented a case study of TIMES OF INDIA GROUP for innovations in marketing strategies, which are product, price, promotion and distribution related. $A$ survey has been conducted by the authors on a recent innovation in marketing strategy of TRIMMING and SLIMMING the size of the newspaper. The data collected from 357 readers of Bangalore are analysed. The readers in general are not only positive to these changes but also have observed them keenly. Such understanding of sensitivity of readers is crucial for the success of marketing strategies.

Newspapers play a critical role in informing general public about news and events. Their views on these would mould the opinions and attitudes of the people. The print media, in particular the newspapers have not only exposed the evils of the society but also have highlighted

† DrM. K. Sridhar is a Reader at Canara Bank School of Management Studies, P.G. Department of Management, Bangalore University, Bangalore.

† Mr A. R. Sainath is a Principal at S.M.S.G College, Bangalore. the positive developments, achievements and experiments. Journalism has been the core of newspaper in India. Of late, they are emerging more as product rather than instruments of journalism. They have emerged like any other consumer, industrial or service products.

\section{NEWSPAPERS AS PRODUCTS}

Newspaper as a product enjoys unique features, which no other product has. It is purchased and read every day by the readers who are the 
consumers of the product. Only literate sections of the society can consume this product. As it constitutes the habit of the reader's it exercises immense influence on them. It even moulds their attitudes, thinking and actions. Because of huge advertisement revenue, it is low priced even though the actual cost is number of times more. It enjoys high degree of brand loyalty and frequency and the extent of shift of readers from one newspaper to another is very limited. They need to be highly dynamic, as they have to cater to the changing needs and expectations of their readers.

\section{NEWSPAPER INDUSTRY IN INDIA}

Indian press has completed more than two centuries of fruitful existence. It was James Augustus Hicky who started the first newspaper 'Bengal Gazette' in 1780. Later on, John Burton and James Mackenzie started Guardian in 1818. Girish Chandra Ghosh established 'The Bengalee' in 1868. Some of the leading newspapers during early 19th century were the 'Bengal Harkaru', 'Morning post', 'Telegraph', 'Calcutta Courier', 'Oriental Star', 'India Gazatte' and 'Asiantic Mirror'.

The newspapers have played an effective and constructive role in Indian struggle for independence. Mahatma Gandhi, Balagangadhar Tilak, Gopal Krishna Gokhale, Bipin Chandrapal, Dadabai Navroji, started newspapers in order to spread and disseminate the message of freedom struggle. Many revolutionaries extensively used this media for creating awareness among people. Even after independence, the role of newspapers continued.

\section{TRENDS IN NEWSPAPER INDUSTRY}

Newspaper industry in India has witnessed various trends over the years. It has become capital intensive requiring crores of rupees of investment on materials and machines. The advertisement revenue has increased to more than $60 \%$ of the total revenue. Feature articles, fortnightly features, continuation stories have become a common feature. Layout is playing a very important role in appearance and presentation. Modular layout is now being adopted which is based on building block concept. Technological upgradation has become the order of the day. Satellite transmission is used for sending texts and photographs. Satellite editions are becoming popular. The industry is becoming more and more reader's oriented which is in tune with the modern marketing concept.

These trends have brought about paradigm shift in the philosophy and practice of the contemporary newspaper industry in India.

\section{CHANGES IN ENVIRONMENT}

The macro and micro environment of the newspaper industry in India has undergone significant changes in the last decade. The mass media is witnessing tremendous transiormation towards electronic and Internet media. The number of viewers and surfers is increasing day by day. The reading habits of people are also undergoing revolutionary changes. They have become more of viewers and seers rather than readers. The average time devoted for reading has significantly come down.

The competition within the industry and outside is becoming more and more intense. The total time available for a person to read, write, etc., has not increased but the mediums have increased. This is resulting in more media 
competition for the share in the mind and heart of the readers. The number of newspapers in English and other vernacular languages has increased over the years. Their circulation, readership and editions have also increased. Hence, the competition within the industry has become very intense for increasing the slice of the cake.

On the other hand, the competition from electronic and other media has also increased. Such competition from within and outside is not only in terms of circulation but also in case of advertisement revenue. The advertisers of the present day have alternative medias for promoting their goods and services. These changes have created serious constraints on the survival and growth of newspaper industry in India because of the pressure on their circulation and profitability. This scenario has thrown up many opportunities and threats to the industry.

\section{RESPONSE OF THE INDUSTRY}

The newspaper industry in India has responded proactively to these opportunities and threats. The newspapers, individually and collectively, are designing short, medium and long term plans and strategies for their survival and growth. These are in terms of product, price, promotion and distribution.

\section{FOCUS ON MARKETING}

The response of the newspaper industry in India has been one of focusing more and more on marketing, which was not only neglected but also ignored all these years. Such a focus on marketing is resulting in the designing of a different kind of marketing programme. a) Product mix : There is creative mix of hard and soft news in addition to providing global perspective with a local flavour. Aspects of packaging like colour, layout, etc. have become more relevant. Supplements have increased role to play in the designing of the product features. Reader interest innovations are also playing important role.

b) Price mix: Affordability has become a motivating factor for purchasing the newspapers. The reduction in price and differential pricing, have become very common in the industry. The price wars have become order of the day.

c) Promotion mix: High visibility has become the order of the game. Need for Brand awareness and recall have compelled the newspapers to resort to massive promotion through different medias. Innovative promotions have increased the curiosity of the readers.

d) Distribution mix: Effective distribution at the right time and at the right place, has become important. The selection, appointment and terms and conditions of the agents are very crucial. The role of hawkers is increasing .

e) Segmentation, targeting and positioning : The basis for segmentation of markets of newspapers has undergone sea change. New segments like youth, women, sports lovers, business minded ones have been identified and targeted by many newspapers. Further, the positioning of newspapers is given importance by projecting the distinct features. 


\section{INNOVATIONS IN MARKETING STRATEGIES}

With the intensification of competition within and outside the industry, the newspapers have started designing and implementing various marketing strategies with regard to product, price, distribution, segments and positioning. As marketing itself was of recent origin with newspaper industry in India, most of the marketing strategies were either pioneers or innovations.

- 'Rajastan Patrika' had a virtual monopoly in Rajasthan which was broken by Madhya Pradesh based 'Dainik Bhaskar' with the help of innovative marketing strategies. innovative direct mailers, introduction of colour pages, advertisements on Zee TV and sponsorship of awards and programmes helped 'Dainik Bhaskar' in this regard.

- 'Dainik Bhaskar' also overtook 'Nayi Duniya' by starting more editions, colour printing on glazed paper, prominent advertising in the main line english dailies and magazines. In Madhya Pradesh, it adopted the strategy of selling the state first and then selling the newspaper. Even during the days of tension and curfew, a team of boys cycled down to remote areas and dropped 'Dainik Bhaskar'. Suppliments like Madhurima, Navrang, Rasrang and Swad were published for readers of different age groups.

- 'Navabharath' started its edition in Navimumbai rather than in Mumbai with the objective of providing a complete newspaper, which was not available in that part. In its business section, a particular focus was given to commodity prices since some of the main commodity markets were in that region. Keeping in mind the Mumbaits passion for doing crosswords, it introduced three crosswords on sports and films.

Eenadu, Malayala Manorama, Dinatanthi and Navabharath splashed their pages with colour as early as 1991. In fact English dailies like Times of India, Deccan Herald and Indian Express introduced this strategy much later. Pune Times, The Telegraph, The Statesman, and Business Standard also introduced colour printing in order to improve the appearance and also to attract the readers.

- Marathiya Murusu in Tamil and Karnataka Malla in Kannada and Kala Kaumudi in Malyalam were started in Mumbai exclusively to cater to the readers of these languages as it took few days for the established papers to reach Mumbai. This innovative strategy of some of these newspapers gave them a good beginning for a resonable circulation which would have been difficult in the normal course.

- Some newspapers increased their circulation by reporting extensively on certain natural calamities. Karnataka Malla and Kala Kaumudi gave wide coverage to Latur earthquake and Gulf war respectively. This brings out an innovation that more people would start reading a newspaper if they cover extensively an event in which they are interested.

- In order to cater to the increasing need for business news, few newspapers ventured into starting either financial dailies or 
supplements or few pages of business news. Noteworthy among them are Karobar started by Amar Ujala, Vanigamani by Dinamani, Arthamanthan by Sakal papers and Vyapar by Janmabhoomi. Their success depended more on focussing upon small traders, industry, farmers and investors. Their appropriate positioning also contributed in this regard.

- The emergence of Vijaya Karnataka as No. 1 Kannada daily is a case study for aggressive marketing of a newspaper with extensive distribution network and appropriate pricing strategy. In a matter of two years, this newspaper overtook Prajavani which was an established leader.

The above marketing strategies are innovations in real sense because they were designed and implemented either for the first time or with a new orientation and dimension. All these and many others have brought marketing to the centrestage of newspaper industry in India.

This discussion on innovations in marketing strategies would not be complete without referring to the efforts of Times of India group. In fact, it emerges as a good case study of print media in India with regard to innovative marketing strategies.

\section{CASE STUDY OF TIMES OF INDIA GROUP}

The first edition of the Bombay Times and Journal of Commerce later to be called the Times of India, was launched in Bombay in 1838. After several years of change, evolution and growth, Bennett, Coleman and Company Limited was established with the principle objective of publishing newspapers, journals, magazines and books. Today, Times of India Group is India's largest media house. It is a multi edition, multi product, multi media organization and has to its credit several leading publications. Among them are the Times of India, The Economic Times, Navabharath Times, Maharastra Times, Femina and Filmfare.

The Times of India is the flagship brand of the group. It is India's premier English daily and worlds largest circulated English broadsheeet daily. It is published from 10 cities across India, has a circulation of over 21,44,842 copies and is read by over 4.42 million people every day . The Economic Times is India's largest and among the world's top three business dailies. It is published simultaniously from seven cities across India and is read by over one million people every day.

Times of India group is a case study for innovations in marketing strategies in all respects. This is evident from the review of various strategies innovated from time to time.

a. Product Related Strategies: The group introduced and successfully implemented various marketing strategies with regard to the contents, layout and packaging of the newspaper. Recruitment advertisements in colour, tender advertisements under different segments like catering, power, stationery, etc. times classifides dot com in 23 categories, introduction of colour printing in the Bangalore edition are some of these strategies. In addition, innovative supplements is also another attraction. Total of eleven supplements are brought out per week in case of Bangalore edition. They include Bangalore Times, 
Classifides, Men and Women, Education Times, Ascent and Financial Times. It brought out a special supplement called IT Ascent in order to cope up with the IT boom. Many booklet presentations were brought out from time to time keeping pace with certain events and developments.

Giving importance to local news and events is another strategy followed by this group. Hapennings in the respective cities, weather conditions, entertainment, grievances, sports and other events are covered prominently. A supplement exclusively catering to local hapennings is also brought out. For example Bangalore Times is brought on six days of the week and this supplement caters only to hapennings in Bangalore.

The product strategies of Economic Times are also similar to but with variance and distinction. Layout and appearance are given primary importance. Lot of visuals and caricatures are used to make the presentation more effective. Three supplements namely Investors Guide, Brand Equity and Corporate Dossier are brought out every week to cater to the needs of the target segments of readers. Occassionally, Economic Times also brings out, booklet presentations like Brand Equity Quiz book and Strategic Marketing which has now become a periodic priced publication.

b. Price Related Strategies: Price paid by the readers of newspaper was considered insignificant in Indian conditions until Times of India group brought down the prices. This opened a new era in the marketing strategies of newspapers in India. Times of India resorted to an invitation price of Rs 1.50 and Rs 1 in important locations of India like New Delhi and Bangalore. This strategy took the rivals by surprise and compelled them to follow the suit. The circulation of Times of India not only increased but also surpassed that of the main rivals like Hindustan Times in New Delhi and Deccan Herald in Bangalore.

The Economic Times also followed a similar strategy. Few years back, it substantially increased the size of the market category through its promotion price of one-rupee-per -copy edition in Mumbai. This made a large number of readers ordering their own copies. An invitation price of two rupees on weekdays was also introduced in many cities. The price of the paper during weekends like Saturday and Sunday has been increased to seven rupees. This prompted many readers to buy the newspapers only for five days in a week. This strategy also brought into its fold many readers who would not have purchased the paper in the normal course .

c. Promotion Related Strategies: The group resorted to various promotion strategies, which are innovative in nature. In fact, these strategies were eye openers to many as people thought that newspapers are to promote others products but not their own. Times of India group distributed free samples in select areas, offered special discounts for the tickets of select programmes, organized 
various contests and events like public speaking etc.,and started 'Newspaper in Education' programme in various schools. Regular advertisements are given on hoardings. It launched a massive campaign to build its brand image which they want to be synonymous with the term 'India'.

As far as Economic Times is concerned, some innovative strategies introduced include ET Club, ET awards for corporate excellence and special pull outs on various occasions. ET Club is mainly meant for students who will get the paper in bulk at their institutions. Panel discussions, workshops and seminars are organized for members at frequent intervals. As part of ET Club activities, the senior executives of the paper visit the institutions and deliver lectures on corporate matters and also conduct ET awareness tests. This strategy introduces the Economic Times to the students who would make it a habit as and when they grow up in the corporate ladder.

All these strategies of Times of India group over a period of time have made marketing very important in increasing not only the circulation but also the ad revenue. They became innovators in the sense that they are the pioneers of these strategies, which other picked up later on. One such recent innovative strategy of this group is the slimmer and livelier paper by pruning the size. This is introduced with effect from 16th of May 2002 for Times of India and Ecnomic Times.

\section{TRIMMED AND SLIMMED PAPER - AN EMPIRICAL STUDY}

Times of India Group introduced a slimmer but not lighter, livelier but not frivolous newspaper in the recent months. This slimmer, easy to handle, sleeker and contemporary newspaper started a new trend in newspaper industry of India. Some newspapers introduced this strategy little earlier or later in order to match with the strategy of Times of India Group. As this is a new precedent in India, the authors undertook a survey of 357 readers of Times of India and Economic Times in Bangalore. The objective was to ascertain the immediate response and reaction of the readers towards this latest strategy of a newspaper in general and Times of India Group in particular. This was carried out during June, 2002.

\section{The Methodology:}

A structured questionnaire was distributed to 400 readers selected on random basis. The MBA students of Canara Bank School of Management Studies, Bangalore University collected the primary data from the readers. The questionnaire consisted of certain background details of the readers like age, gender, occupation, annual household income and the length of the habit of reading Times of India Group newspapers. It also found out the observations of the readers towards the recent changes in size, layout, content and supplements. Their response to these changes was also ascertained by giving five scales of agreement or disagreement regarding the positive and negative dimensions of the recent changes. The data collected were analysed with the help of percentages, frequency tables and mean scores. 
Data Analysis:

The profile of respondents was that $73 \%$ were less than 40 years of age, $59 \%$ were male, $37 \%$ were employed, $38 \%$ were students and $64 \%$ were having annual household income of less than two lakhs. $60 \%$ of the readers of Times of India and $50 \%$ of Economic Times have been reading the respective newspaper for not more than 3 years.

TABLE 1

\section{DISTRIBUTION OF RESPONDENTS BASED ON THEIR EXTENT OF OBSERVATION OF CHANGES}

\begin{tabular}{|l|l|l|l|l|l|l|}
\hline \multirow{2}{*}{ Nature of change } & \multicolumn{6}{|c|}{ Extent of change } \\
\cline { 2 - 7 } & \multicolumn{2}{|c|}{ No change } & \multicolumn{2}{c|}{ Minor change } & \multicolumn{2}{c|}{ Major change } \\
\cline { 2 - 7 } & Times of India & Economic Times & Times of India & Economic Times & Times of India & Economic Times \\
\hline Size & $14(4.07)$ & $22(14.29)$ & $122(35.46)$ & $50(32.47)$ & $208(60.47)$ & $82(53.24)$ \\
\hline Loyout & $40(11.63)$ & $28(18.18)$ & $192(55.81)$ & $93(60.39)$ & $112(32.56)$ & $33(21.43)$ \\
\hline Content & $129(37.50)$ & $63(40.91)$ & $172(50.00)$ & $75(48.70)$ & $43(12.50)$ & $16(10.39)$ \\
\hline Supplements & $112(32.56)$ & $53(34.42)$ & $174(50.58)$ & $78(50.65)$ & $58(16.86)$ & $23(14.93)$ \\
\hline
\end{tabular}

NOTE : Figures in brackels are percentages

The above table reveals that $60.47 \%$ of readers of Times of India have treated the recent changes as major ones whereas $53.24 \%$ of readers have treated as major changes in case of size. Another important finding is that more than $50 \%$ of readers of both the newspapers have observed minor changes in case of layout, content and supplements.
The above table was further analysed to arrive at mean-scores. These scores were ascertained after giving weightage of 1,2 and 3 to answers like no change, minor changes and major changes. The summary is given below. 
TABLE 2

\section{MEAN SCORES OF THE EXTENT OF CHANGES OBSERVED BY READERS OF TIMES OF INDIA}

\begin{tabular}{|l|c|c|c|c|}
\hline \multirow{2}{*}{ Nature of change } & \multicolumn{4}{|c|}{ Extent of change } \\
\cline { 2 - 5 } & No change & Minor change & Major change & Mean Score \\
\hline Size & 14 & 244 & 624 & 2.56 \\
\hline Layout & 40 & 384 & 336 & 2.20 \\
\hline Content & 129 & 344 & 132 & 1.76 \\
\hline Supplements & 112 & 348 & 174 & 1.84 \\
\hline Mean Score & & & & 2.09 \\
\hline
\end{tabular}

TABLE 3

\section{MEAN SCORES OF THE EXTENT OF CHANGES OBSERVED BY READERS OF ECONOMIC TIMES}

\begin{tabular}{|l|c|c|c|c|}
\hline \multirow{2}{*}{ Nature of change } & \multicolumn{4}{|c|}{ Extent of change } \\
\cline { 2 - 5 } & No change & Minor change & Major change & Mean Score \\
\hline Size & 22 & 100 & 246 & 2.39 \\
\hline Layout & 28 & 186 & 99 & 2.03 \\
\hline Content & 63 & 150 & 48 & 1.69 \\
\hline Supplements & 53 & 156 & 69 & 1.81 \\
\hline Mean Score & & & & 1.98 \\
\hline
\end{tabular}

From the above tables, it can be inferred that the mean scores of the readers of Times of India are more than that of Economic Times in case of all the dimentions like size, layout, content and supplements. Even the average mean score of 2.09 of Times of India is more than that of 1.98 of Economic Times. This analysis brings out the fact that the recent changes in the newspapers were more visible to readers of Times of India than that of Economic Times. 
TABLE 4

\section{DISTRIBUTION OF READERS OF TIMES OF INDIA BASED ON RESPONSE TO CHANGES}

\begin{tabular}{|c|c|c|c|c|c|}
\hline Nature of change & $\begin{array}{c}\text { Strongly } \\
\text { agree }\end{array}$ & Agree & Undecided & Disgagree & $\begin{array}{c}\text { Sitrongly } \\
\text { disggree }\end{array}$ \\
\hline $\begin{array}{c}\text { 1. Change in size is } \\
\text { a. Easy to handle }\end{array}$ & $97(28.20)$ & $164(47.67)$ & $13(3.78)$ & $37(10.76)$ & $33(9.59)$ \\
\hline b. Means to cut cost & $101(29.36)$ & $118(34.30)$ & $66(19.19)$ & $42(12.21)$ & $17(4.94)$ \\
\hline $\begin{array}{c}\text { 2. Change in layout is } \\
\text { a. Impressive }\end{array}$ & $71(20.64)$ & $162(47.09)$ & $42(12.21)$ & $59(17.15)$ & $10(2.91)$ \\
\hline $\begin{array}{c}\text { b. Difficult to read } \\
\text { 3. Content hos }\end{array}$ & $55(15.99)$ & $76(22.09)$ & $46(13.37)$ & $138(40.12)$ & $29(8.43)$ \\
\hline $\begin{array}{c}\text { a. Improved } \\
\text { b. Not improved }\end{array}$ & $68(19.77)$ & $132(38.37)$ & $67(19.48)$ & $55(15.99)$ & $22(6.39)$ \\
\hline $\begin{array}{c}\text { 4. Change in } \\
\text { supplements is } \\
\text { a. Contemporary }\end{array}$ & $48(13.95)$ & $182(52.91)$ & $74(21.51)$ & $27(7.85)$ & $13(3.78)$ \\
\hline b. Irrelevont & $35(10.17)$ & $79(22.97)$ & $88(25.58)$ & $129(37.50)$ & $13(3.78)$ \\
\hline
\end{tabular}

NOTE : Figures in brackels are percentages.

The above table reveals that more than $75 \%$ of the readers agree or strongly agree that the change in size is easy to handle whereas $64 \%$ agree or strongly agree that it is a means to cut cost. It can also be observed that more percentage of readers $(19.19 \%)$ are undecided in case of means to cut cost than $3.78 \%$ in case of easy to handle. Nearly $20 \%$ of the readers disagree or strongly disagree that it is easy to handle and $17 \%$ disagree or strongly disagree to the means to cut cost. More percentage of readers agree or strongly agree to the change in layout, content and supplement than the percentage of readers who disagree or strongly disagree 
TABLE 5

\section{DISTRIBUTION OF READERS OF ECONOMIC TIMES BASED ON RESPONSE TO CHANGES}

\begin{tabular}{|c|c|c|c|c|c|}
\hline Nafure of change & $\begin{array}{l}\text { Strongly } \\
\text { agree }\end{array}$ & Agree & Undecided & Disagree & $\begin{array}{l}\text { Strongly } \\
\text { disagree }\end{array}$ \\
\hline \multicolumn{6}{|l|}{ 1. Change in size is } \\
\hline a. Easy to handle & $46(29.87)$ & $69(44.81)$ & $10(6.49)$ & $19(12.34)$ & $10(6.49)$ \\
\hline b. Means to cut cost & $30(19.48)$ & $56(36.36)$ & $31(20.13)$ & $27(17.53)$ & $10(6.50)$ \\
\hline \multicolumn{6}{|l|}{ 2. Change in layout is } \\
\hline a. Impressive & $33(21.43)$ & $69(44.81)$ & $16(10.39)$ & $25(16.23)$ & $11(7.14)$ \\
\hline b. Difficult to read & $16(10.39)$ & $32(20.78)$ & $24(15.58)$ & $54(35.06)$ & $28(18.19)$ \\
\hline \multicolumn{6}{|l|}{ 3. Content has } \\
\hline a. Improved & $23(14.94)$ & $78(50.65)$ & $26(16.88)$ & $13(8.44)$ & $14(9.09)$ \\
\hline b. Not improved & $19(12.34)$ & $28(18.18)$ & $40(25.97)$ & $51(33.12)$ & $16(10.39)$ \\
\hline \multicolumn{6}{|l|}{$\begin{array}{l}\text { 4. Change in } \\
\text { supplements is }\end{array}$} \\
\hline a. Contemporary & $18(11.69)$ & $81(52.60)$ & $27(17.53)$ & $10(6.49)$ & $18(11.69)$ \\
\hline b. Irrelevant & $18(11.69)$ & $21(13.64)$ & $45(29.22)$ & $55(35.71)$ & $15(9.74)$ \\
\hline
\end{tabular}

NOTE : Figures in brackets are percentages.

The above table brings out that $74 \%$ of readers agree or strongly agree that the change in size is easy to handle whereas $56 \%$ agree or strongly agree that it is a means to cut cost. The percentage of readers $(20.13 \%)$ who are undecided in case of means to cut cost is more than that of readers who opine that it is easy to handle. $19 \%$ of readers either disagree or strongly disagree that it is easy to handle and $24 \%$ disagree or strongly disagree for means to cut cost. With regard to change in layout, $66 \%$ agree or strongly agree that it is impressive but $31 \%$ feel that it is difficult to read. $53 \%$ of readers disagree or strongly disagree that it is difficult to read. In case of improvement of content, $65 \%$ agree or strongly agree whereas $30 \%$ agree that there is no improvement. A similar trend is observable in case of change in supplements also. 
TABLE 6

MEAN SCORES OF READERS RESPONSE TO CHANGES

\begin{tabular}{|c|c|c|}
\hline Noture of change & $\begin{array}{c}\text { Times of } \\
\text { India }\end{array}$ & $\begin{array}{c}\text { Economic } \\
\text { Times }\end{array}$ \\
\hline $\begin{array}{c}\text { 1. Change in size is } \\
\text { a. Easy to handle }\end{array}$ & 3.74 & 3.60 \\
\hline b. Meons to cut cost & 2.29 & 2.55 \\
\hline $\begin{array}{c}\text { 2. Change in layout is } \\
\text { a. Impressive }\end{array}$ & 3.65 & 3.57 \\
\hline $\begin{array}{c}\text { b. Difficult to read } \\
\text { 3. Content has }\end{array}$ & 3.03 & 3.30 \\
\hline b. Improved & 3.49 & 3.53 \\
\hline $\begin{array}{c}\text { 4. Change in supplements is } \\
\text { a. Contemporary }\end{array}$ & 3.6 & 3.46 \\
\hline $\begin{array}{l}\text { b. Irrelevant } \\
\text { Average mean score of } \\
\text { positive statements }\end{array}$ & 3.01 & 3.18 \\
\hline $\begin{array}{l}\text { Average meon score of } \\
\text { negative statements }\end{array}$ & 2.79 & 3.03 \\
\hline
\end{tabular}

The above table brings out that the mean score of easy to handle is more than that of means to cut cost in case of Times of India. Same is the case with impressiveness of change of layout, improvement of content and contemporariness of changes in supplements. In other words, the readers of Times of India have welcomed the changes more positively.
With regard to Economic Times also, similar trend is evident. The mean scores in case of change of size, easy to handle is 3.60 and means to cut cost is 2.55 . The mean scores of impressive change of layout, improved content and contemporariness of supplements are more than that of difficult to read, no improvement in content and irrelevant supplements.

On the whole, mean scores of all positive statements in case of Times of India are more than that of all negative statements. Same is the case with the readers of Economic Times also. On comparison between Times of India and Economic Times, it is evident that the mean scores of Times of India are more than that of Economic Times in case of positive statements. This is not so with negative statements.

\section{DISCUSSION ON FINDINGS}

The entire analysis of the primary data furnished above brings out one important issue to the fore. That is the perception of the readers to the recent marketing strategy of pruning the size of the newspaper. No doubt, the reader is getting less quantity of newspaper but still they have welcomed the same in a positive way. This must be due to not only to the innovation but also proper packaging and communication of the change. This is evident from the way the publishers of Times of India group communicated that the pruning is in confirmity with the international practice. If this is the extent of welcome in the initial stages, it will improve and increase in the days 10 come and the readers would be habituated to these changes. 


\section{CONCLUSION}

Thus the marketing strategies followed by various newspapers in India have certainly benefited them by increasing their circulation and profitability. These strategies have also become very convenient to handle competitors. If these strategies were more innovative, the results would be more positive. The case study of Times of India Group has established without any doubt that the readers of Indian newspapers have very positively responded to the various innovations in marketing strategies. This augurs well for marketing in general and newspaper industry in India in particular. 


\section{Sources}

( Ahuja B. N. : "History of Indian press growth of newspapers in India". Surgeet Publications, Delhi, 1988.

- Asha K.: "Newspaper as a catalyst of rural change", Social Welfare, July, 1999.

- Anand P., Raman and Sukumar : "Quality and Strategy", Business Today, Dec. 7 , 1998.

( Balasubramanian : "Technological changes in the newspaper industry", The Economic Times, Oct. 22, 1992.

- "Blasing a trial in electronic publishing", The Economic Times, March 5, 1991.

- "Cratting a design, The inside story", The Economic Times, March 5, 1991.

口 Chaya, Pareena and Sukumar: "The strategic P", Business Today, Dec. 7, 1997.

口 Duane Bradley: "The newspaper \& its place in a democracy". Strelling Publishing Pvt. Ltd., Delhi.

- G. Binney Dibblee: "The newspaper", Willhoing and Norgate, London.

口 Giri Lal Jain: "Newspaper - Why the press is different", Times of India, Nov. 12 , 1987.

- "Glazed newsprint" The Economic Times, July 20, 1998.

- Gary Hamel : "Strategy innovation and the quest for value", Sloan Management Review, Winter - 1998.

口 Hemalatha and others: "Newspaper readings and opinion survey of the peaders of The Hindu in Tirupati town", Herald of Library Science, Jan. 1992.
Michael Porter : "what is strategy", Harward business review, Nov - Dec 1996.

- "Newspaper in a changing market place", Times of India, April 4, 1989.

( Raghavan : "The press in India - a New History", Gyan Publishing House, New Delhi, 1994.

- Raghu Pillai : "Newspaper marketing formula for success", College of Management, Mysore, SDM Newsletter.

- Raji Memon : "Breaking the regional mould", The Economic Times, Sep. 14, 1994.

- Shuchi Bansal: "A new edition for the Hindi press", Business World, Aug. 7, 1997.

- Shuchi Bansal and Yassir : "There is no victory in vernacular", Business World, Nov. 7, 1997.

- Sumana Raman: "When you see color think of news", Business World, Feb. 22, 1998.

Venkateshvaralu H. and V. Shekar : "What makes a good newspaper", Indian Management, Feb. 1990.

口 Vidhyadhara Reddy A. and K. Shankaraiah : "Brand switching of customers", Indian Management, Dec. 1998.

- Vikram Doctor, M. P. Jain : "Desert storm" Business India, Feb. 10, 1997.

口 Vikram Doctor: "A media moguls, Mumbai move", Business World, Dec. 22, 1997.

口 Ved Bushan Sen : "A strategic clash", Business Today, Feb. 1997. 